\title{
Effect of Row Ratio and Fertility Level on Nutrient uptake by Maize in Maize-Soybean Intercropping System
}

\author{
Pragya Pandey $^{1}$, Anshita Bajpai ${ }^{2}$ and R. K. Bajpai ${ }^{3}$ \\ ${ }^{1}$ Krishi Vigyan Kendra, Bemetara (Chhattisgarh), India \\ ${ }^{2}$ Department of Agronomy, I.G.K.V., Raipur, (Chhattisgarh), India \\ ${ }^{3}$ Indira Gandhi Agricultural University, Raipur (Chhattisgarh), India \\ *Corresponding author
}

\section{A B S T R A C T}

This field experiment was conducted during the kharif season of 2014 and 2015 at the Indira Gandhi Krishi Vishwavidyalaya, Raipur (C.G) to find out the effect of

\section{Keywords}

Crop, nutrient Maize, soybean (RDF)

\section{Article Info}

Accepted:

18 May 2020

Available Online:

10 June 2020 crop arrangement and nutrient management on availability of nutrients under maize and soybean intercropping system. Treatments comprised of six cropping arrangements viz. sole maize $\left(\mathrm{C}_{1}\right)$, sole soybean $\left(\mathrm{C}_{2}\right)$, two replacement series of maize + soybean $\left(2: 2, \mathrm{C}_{3}\right.$ and $\left.2: 4, \mathrm{C}_{4}\right)$, two additive series in which two rows $\left(\mathrm{C}_{5}\right)$ and one row $\left(\mathrm{C}_{6}\right)$ of soybean were added in-between two rows of maize and four fertility levels viz. $125 \%$ recommended dose of fertilizer (RDF) $\left(\mathrm{F}_{1}\right), 100 \% \mathrm{RDF}$ $\left(\mathrm{F}_{2}\right), 75 \%$ RDF $\left(\mathrm{F}_{3}\right)$ and $50 \% \mathrm{RDF}\left(\mathrm{F}_{4}\right)$. Uptake of $\mathrm{N}$ and $\mathrm{P}$ was higher in grain than stover but in case of $\mathrm{K}$ uptake reverse trend was recorded. Maize under intercropping system performed better than sole maize. Replacement series 2:4 maize: soybean recorded highest uptake of NPK over remaining treatments. Uptake of nutrients followed an increasing trend with increase in NPK dose under nutrient management. $125 \%$ RDF performed better than other fertility levels.

\section{Introduction}

Plants take up essential elements from the soil through their roots and from the air (mainly consisting of nitrogen and oxygen) through their leaves. The root, especially the root hair, is the essential organ for the uptake of nutrients. Nutrients can be moved within plants to where they are most needed. Soil act as sink of nutrients for plants; so if soil is productive higher will be the production. But continuous farming on a land without sustaining its fertility has made soil less productive.

To control the degradation of soil fertility we need to use nutrient source more specifically and more nutrient-efficient crops to increase and maintain crop yields needed for ecologically sustainable production of food and biomass (Fageria et al., 2008 and Spiertz and Ewert 2009). 
Intercropping of cereals with legumes is quite popular among smallholder farmers due to the ability of the legume to fix atmospheric nitrogen which address the problem of declining levels of soil fertility (Matusso et $a l ., 2014)$. In cereal + legume intercropping systems, the combination of a tall cereal with an adventitious root system and a shortstatured legume with a deep tap root utilises space and time more efficiently than a sole cereal crop. Maize and soybean is a good example of this system. Intercropping of legumes with maize is considered to be better way for securing nitrogen economy and increasing yield of maize as well providing bonus yield of soybean. This also enhances the productivity per unit time and space and higher net returns of intercropping system over monoculture (Thayamini and Brintha, 2010).

\section{Materials and Methods}

This field experiment was conducted during the kharif season of 2014 and 2015 at the Instructional cum Research Farm, Indira Gandhi Krishi Vishwavidyalaya, Raipur situated in central parts of Chhattisgarh. Hybrid maize variety Hishell and soybean variety Jawahar Soybean 97-52 (JS 97-52) were grown on clayey soil under the experiment. Soil of the site showed $\mathrm{pH} 7.5$ (neutral) with available $175.61 \mathrm{~kg} \mathrm{ha}^{-1}$ Nitrogen (low), $10.752 \mathrm{~kg} \mathrm{ha}^{-1}$ Phosphorus (medium) and $330.736 \mathrm{kgha}^{-1}$ Potash (high) at the depth of $0-30 \mathrm{~cm}$. The experiment was laid out in Factorial Randomised Block Design with three replications. Each replication was divided into 24 experimental treatments. Treatments comprised of six cropping arrangements viz. sole maize $\left(\mathrm{C}_{1}\right)$, sole soybean $\left(\mathrm{C}_{2}\right)$, maize+soybean in 2:2 $\left(\mathrm{C}_{3}\right)$ and 2:4 $\left(\mathrm{C}_{4}\right)$ rows in replacement series and two additive series (two rows of soybean $\left(\mathrm{C}_{5}\right)$ and one row of soybean $\left(\mathrm{C}_{6}\right)$ planted inbetween two rows of maize and four fertility levels viz. $125 \%$ recommended dose of fertilizer (RDF) $\left(\mathrm{F}_{1}\right), 100 \% \operatorname{RDF}\left(\mathrm{F}_{2}\right), 75 \%$ RDF $\left(\mathrm{F}_{3}\right)$ and $50 \% \operatorname{RDF}\left(\mathrm{F}_{4}\right)$. Recommended dose of fertilizer used for maize was $110 \mathrm{~kg} \mathrm{~N}$ $\mathrm{ha}^{-1}, 60 \mathrm{P}_{2} \mathrm{O}_{5} \mathrm{~kg} \mathrm{ha}^{-1}$ and $40 \mathrm{~K}_{2} \mathrm{O} \mathrm{kg} \mathrm{ha}^{-1}$ and for soybean was $20 \mathrm{~N} \mathrm{~kg} \mathrm{ha}^{-1}, 60 \mathrm{P}_{2} \mathrm{O}_{5} \mathrm{~kg} \mathrm{ha}^{-1}$ and $40 \mathrm{~K}_{2} \mathrm{O} \mathrm{kg} \mathrm{ha}{ }^{-1}$.

To find out the uptake of nitrogen, phosphorus and potassium in seed and stover plant samples were collected at 20, 40, 60, 80 DAS and at harvest. The total (grain + straw) uptake of a particular nutrient was estimated by adding the individual values for grain and straw. The uptake of a particular nutrient was estimated by the formula:

$\begin{gathered}\text { Nutrient utake } \\ \left(\mathrm{kgha}^{-1}\right)\end{gathered}=\frac{\text { Nutrient content }(\%) \mathrm{x} \text { Yield }\left(\mathrm{kgha}^{-1}\right) \text { on oven dry basis }}{100}$

\section{Results and Discussion}

\section{Uptake of nitrogen by maize}

Crop arrangements and nutrient management practices influenced the uptake of nitrogen significantly (Table 2 and 5). The uptake of nitrogen by grain was higher than that of by stover. Highest uptake of nitrogen was observed from the treatment with 2:4 maize + soybean replacement series in plants and in grains also followed by 2:2 maize + soybean crop arrangements. However, the lowest $\mathrm{N}$ uptake by plant and grain was observed in sole maize. Higher N-uptake was perhaps due to the difference in competitive abilities of maize and soybean which may increase $\mathrm{N}$ uptake by cereal and besides this the $\mathrm{N}$ acquisition may also be attributed to $\mathrm{N}$ transfer to maize from soybean (Ning et al., 2012). In maize and soybean intercropping with differing root and uptake patterns, more efficient use of available nutrients may occur, and higher uptake of nitrogen in the intercrop have been reported. Similar findings were reported by Undie et al., (2012). 
Significant higher uptake of $\mathrm{N}$ by the plants and grain under $125 \%$ RDF was observed and this was followed by $100 \%$ RDF. While the lowest uptake of nitrogen by plants and grains of maize was seen in the lowest fertility level i.e. 50\% RDF. Francis, 1986 reported the similar trend in maize-cowpea intercropping.

\section{Uptake phosphorus by maize}

Data depicted in table 3 and 5 shows that the phosphorus uptake increased upto 60 DAS and afterwards gradual reduction in uptake was observed. Like nitrogen higher uptake of phosphorus also observed in grains than straw. Highest value of this trait was reported in 2:4 maize + soybean replacement series which was followed by 2:2 replacement series of maize + soybean intercropping. Lowest value of uptake by maize plant and grain was observed in sole maize throughout the crop growth period. Intercropping systems facilitate the spatial and temporal increase in nutrients uptake, might be the reason behind the higher $\mathrm{P}$ uptake (Flores et al., 2013). Spatial nutrients uptake can be increased through the increasing root mass, while temporal advantage in nutrients uptake occur when crops in an intercropping system have their peak nutrients demands at different times. In respect to nutrient management, data showed that application of $125 \% \operatorname{RDF}\left(\mathrm{F}_{1}\right)$ increased the phosphorus uptake of maize at all the observational stages over rest of the treatments. However, minimum uptake of phosphorus by plants as well as by grain was observed under $50 \%$ RDF $\left(\mathrm{F}_{4}\right)$ during both the years as well as on the basis of mean. Singh et al., (1998) and Francis (1986) confirms this result.

\section{Uptake of potassium by maize}

In general, $\mathrm{N}$ and $\mathrm{P}$ contents of grain in maize were higher than that in stover. The reverse was true in case of $\mathrm{K}$ content i.e. stover recorded higher $\mathrm{K}$ content than in grain. Higher potassium in straw in comparison to grain is due to luxury consumption of potassium by the crop. Highest potassium uptake was recorded in 2:4, maize + soybean replacement series. This was followed by the replacement series 2:2 maize + soybean. Both additive series were found comparable at all the observational stages for K uptake. While thus trait of both the stover and grain was recorded in sole maize. Similar findings were also reported by Chalka and Nepalia (2006).

Among four nutrient management 125\% RDF and 50\% RDF produced significantly higher and lower potassium uptake respectively at all the growth stages. However, 100\% RDF followed the $125 \%$ RDF regarding potassium uptake throughout the crop growth period. This result is in line with Meena et al., (2006). This might be due to adequate fertilizer supply of plant nutrients in $F_{1}$ led to enhancement of uptake by the crops.

Table.1 Methods used for plant nutrient analysis

\begin{tabular}{|l|l|}
\hline Nutrient & Methods \\
\hline Nitrogen & Micro Kjeldahl (Tandon, 1993) \\
\hline Phosphorus & $\begin{array}{l}\mathrm{HNO}_{3}: \mathrm{HClO}_{4}(9: 4) \text { digestion colour development by Vanadomolybdate } \\
\text { solution followed by spectrophotometric determination (Tandon, 1993) }\end{array}$ \\
\hline Potassium & $\begin{array}{l}\mathrm{HNO}_{3}: \mathrm{HClO}_{4}(9: 4) \text { digestion colour development by Vanadomolybdate } \\
\text { solution followed by spectrophotometric determination Flame } \\
\text { photometric (Tandon, 1993) }\end{array}$ \\
\hline
\end{tabular}


Table.2 Uptake of nitrogen ( $\mathrm{g} \mathrm{g}^{-1}$ plant weight) by maize stover as influenced by the crop arrangement and nutrient management under maize + soybean intercropping system

\begin{tabular}{|c|c|c|c|c|c|}
\hline \multirow[t]{2}{*}{ Treatments } & \multicolumn{4}{|c|}{$\mathrm{N}$ uptake ( $\mathrm{g} \mathrm{g}^{-1}$ plant weight) } & \multirow{2}{*}{$\begin{array}{l}\begin{array}{l}\text { N uptake } \\
\left(\mathbf{k g ~ h a}^{-1}\right)\end{array} \\
\text { At harvest }\end{array}$} \\
\hline & 20 DAS & 40 DAS & 60 DAS & 80 DAS & \\
\hline \multicolumn{6}{|c|}{ Crop arrangement } \\
\hline $\mathrm{C}_{1}$ & 0.068 & 0.891 & 1.394 & 1.536 & 67.44 \\
\hline $\mathrm{C}_{3}$ & 0.077 & 0.948 & 1.651 & 1.809 & 84.65 \\
\hline $\mathrm{C}_{4}$ & 0.085 & 1.047 & 1.812 & 2.006 & 94.90 \\
\hline $\mathrm{C}_{5}$ & 0.073 & 0.920 & 1.522 & 1.652 & 75.69 \\
\hline $\mathrm{C}_{6}$ & 0.072 & 0.917 & 1.472 & 1.607 & 75.77 \\
\hline SEm \pm & 0.002 & 0.020 & 0.035 & 0.048 & 2.20 \\
\hline $\mathrm{CD}(\mathrm{P}=0.05)$ & 0.005 & 0.055 & 0.098 & 0.134 & 6.17 \\
\hline \multicolumn{6}{|c|}{ Nutrient management } \\
\hline $\mathbf{F}_{1}$ & 0.089 & 1.072 & 1.979 & 2.186 & 104.86 \\
\hline $\mathbf{F}_{2}$ & 0.077 & 0.962 & 1.662 & 1.843 & 85.31 \\
\hline $\mathbf{F}_{3}$ & 0.070 & 0.898 & 1.430 & 1.550 & 72.82 \\
\hline $\mathbf{F}_{4}$ & 0.064 & 0.845 & 1.207 & 1.308 & 55.77 \\
\hline SEm \pm & 0.001 & 0.017 & 0.031 & 0.043 & 1.97 \\
\hline $\mathrm{CD}(\mathrm{P}=0.05)$ & 0.004 & 0.049 & 0.088 & 0.120 & 5.52 \\
\hline
\end{tabular}

$\mathrm{C}_{1}$-Sole maize, $\mathrm{C}_{2}$-Sole soybean, $\mathrm{C}_{3}$-Maize+ soybean, 2:2, $\mathrm{C}_{4}$-Maize+ soybean, 2:4, $\mathrm{C}_{5}$ - Two rows of soybean planted in between two rows of maize, $\mathrm{C}_{6}$-One row of soybean planted in between two rows of maize, $\mathrm{F}_{1}-125 \%$ RDF, $\mathrm{F}_{2}-100 \%$ RDF, $\mathrm{F}_{3}-75 \%$ RDF, $\mathrm{F}_{4}-50 \% \mathrm{RDF}$

Table.3 Phosphorus uptake by maize stover as influenced by the crop arrangement and nutrient management under maize + soybean intercropping system

\begin{tabular}{|c|c|c|c|c|c|}
\hline \multirow[t]{2}{*}{ Trreatments } & \multicolumn{4}{|c|}{$P$ uptake ( $\mathrm{g} \mathrm{g}^{-1}$ plant weight) } & \multirow{2}{*}{$\begin{array}{l}\begin{array}{l}\text { P uptake } \\
\left(\mathbf{k g ~ h a}^{-1}\right)\end{array} \\
\text { At harvest }\end{array}$} \\
\hline & 20 DAS & 40 DAS & 60 DAS & 80 DAS & \\
\hline \multicolumn{6}{|c|}{ Crop arrangement } \\
\hline $\mathrm{C}_{1}$ & 0.0034 & 0.0750 & 0.0911 & 0.0688 & 7.81 \\
\hline $\mathbf{C}_{3}$ & 0.0042 & 0.0865 & 0.1073 & 0.0874 & 10.40 \\
\hline $\mathrm{C}_{4}$ & 0.0048 & 0.0940 & 0.1166 & 0.0930 & 11.94 \\
\hline $\mathbf{C}_{5}$ & 0.0038 & 0.0824 & 0.1003 & 0.0762 & 8.78 \\
\hline $\mathrm{C}_{6}$ & 0.0038 & 0.0800 & 0.0958 & 0.0728 & 8.38 \\
\hline SEm \pm & 0.0001 & 0.0025 & 0.0023 & 0.0024 & 0.26 \\
\hline $\mathrm{CD}(\mathrm{P}=0.05)$ & 0.0003 & 0.0069 & 0.0064 & 0.0068 & 0.72 \\
\hline \multicolumn{6}{|c|}{ Nutrient management } \\
\hline $\mathbf{F}_{1}$ & 0.0052 & 0.1017 & 0.1310 & 0.1030 & 13.10 \\
\hline $\mathbf{F}_{2}$ & 0.0047 & 0.0890 & 0.1120 & 0.0840 & 10.66 \\
\hline $\mathbf{F}_{3}$ & 0.0036 & 0.0770 & 0.0900 & 0.0710 & 8.10 \\
\hline $\mathbf{F}_{4}$ & 0.0027 & 0.0660 & 0.0760 & 0.0600 & 5.98 \\
\hline SEm \pm & 0.0001 & 0.0022 & 0.0020 & 0.0020 & 0.23 \\
\hline $\mathrm{CD}(\mathrm{P}=\mathbf{0 . 0 5})$ & 0.0003 & 0.0062 & 0.0060 & 0.0060 & 0.64 \\
\hline
\end{tabular}

$\mathrm{C}_{1}$-Sole maize, $\mathrm{C}_{2}$-Sole soybean, $\mathrm{C}_{3}$-Maize+ soybean, 2:2, $\mathrm{C}_{4}$-Maize+ soybean, 2:4, $\mathrm{C}_{5}$ - Two rows of soybean planted in between two rows of maize, $\mathrm{C}_{6}$-One row of soybean planted in between two rows of maize, $\mathrm{F}_{1}-125 \%$ RDF, $\mathrm{F}_{2}-100 \%$ RDF, $\mathrm{F}_{3}-75 \%$ RDF, $\mathrm{F}_{4}-50 \%$ RDF 
Table.4 Potassium uptake by maize stover as influenced by the crop arrangement and nutrient management under maize + soybean intercropping system

\begin{tabular}{|c|c|c|c|c|c|}
\hline \multirow[t]{2}{*}{ Treatments } & \multicolumn{4}{|c|}{$\mathrm{K}$ uptake ( $\mathrm{g} \mathrm{g}^{-1}$ of plant weight) } & \multirow{2}{*}{$\begin{array}{c}\begin{array}{c}\text { K uptake } \\
\left(\mathbf{k g ~ h a}^{-1}\right)\end{array} \\
\text { At harvest }\end{array}$} \\
\hline & 20 DAS & 40 DAS & 60 DAS & 80 DAS & \\
\hline \multicolumn{6}{|c|}{ Crop arrangement } \\
\hline $\mathrm{C}_{1}$ & 0.077 & 1.020 & 1.560 & 1.680 & 120.90 \\
\hline $\mathbf{C}_{3}$ & 0.087 & 1.090 & 1.830 & 1.970 & 142.12 \\
\hline $\mathrm{C}_{4}$ & 0.094 & 1.190 & 1.990 & 2.180 & 159.52 \\
\hline $\mathrm{C}_{5}$ & 0.083 & 1.060 & 1.680 & 1.810 & 132.07 \\
\hline $\mathrm{C}_{6}$ & 0.081 & 1.050 & 1.630 & 1.770 & 129.29 \\
\hline SEm \pm & 0.001 & 0.020 & 0.040 & 0.040 & 4.06 \\
\hline $\mathrm{CD}(\mathrm{P}=0.05)$ & 0.003 & 0.050 & 0.110 & 0.100 & 11.35 \\
\hline \multicolumn{6}{|c|}{ Nutrient management } \\
\hline $\mathbf{F}_{1}$ & 0.099 & 1.210 & 2.030 & 2.180 & 170.39 \\
\hline $\mathbf{F}_{2}$ & 0.087 & 1.090 & 1.680 & 1.840 & 143.44 \\
\hline $\mathbf{F}_{3}$ & 0.079 & 1.040 & 1.510 & 1.690 & 126.45 \\
\hline $\mathbf{F}_{4}$ & 0.073 & 0.970 & 1.320 & 1.400 & 106.84 \\
\hline SEm \pm & 0.001 & 0.060 & 0.030 & 0.030 & 3.63 \\
\hline $\mathrm{CD}(\mathrm{P}=0.05)$ & 0.003 & 0.044 & 0.090 & 0.090 & 10.15 \\
\hline
\end{tabular}

$\mathrm{C}_{1}$-Sole maize, $\mathrm{C}_{2}$-Sole soybean, $\mathrm{C}_{3}$-Maize+ soybean, 2:2, $\mathrm{C}_{4}$-Maize+ soybean, 2:4, $\mathrm{C}_{5}$ - Two rows of soybean planted in between two rows of maize, $\mathrm{C}_{6}$-One row of soybean planted in between two rows of maize, $\mathrm{F}_{1}-125 \%$ RDF, $\mathrm{F}_{2}-100 \% \mathrm{RDF}, \mathrm{F}_{3}-75 \% \mathrm{RDF}, \mathrm{F}_{4}-50 \% \mathrm{RDF}$

Table.5 N, P and K uptake grain (At harvest) and grain yield of maize as influenced by the crop arrangement and nutrient management under maize + soybean intercropping system

\begin{tabular}{|c|c|c|c|c|}
\hline \multirow[b]{2}{*}{ Treatments } & \multicolumn{3}{|c|}{ Uptake $\left(\mathrm{kg} \mathrm{ha}^{-1}\right)$} & \multirow{2}{*}{$\begin{array}{c}\text { Grain yield of maize } \\
\qquad\left(\mathrm{q} \mathrm{ha} \mathbf{h}^{-1}\right)\end{array}$} \\
\hline & Nitrogen & Phosphorus & Potassium & \\
\hline \multicolumn{5}{|c|}{ Crop arrangement } \\
\hline $\mathbf{C}_{1}$ & 96.32 & 8.86 & 100.44 & 61.46 \\
\hline $\mathbf{C}_{3}$ & 114.29 & 11.79 & 122.36 & 58.21 \\
\hline $\mathrm{C}_{4}$ & 122.77 & 13.54 & 141.52 & 40.89 \\
\hline $\mathbf{C}_{5}$ & 105.68 & 9.95 & 111.19 & 61.65 \\
\hline $\mathrm{C}_{6}$ & 103.20 & 9.50 & 110.60 & 61.12 \\
\hline SEm \pm & 2.24 & 0.29 & 3.22 & 0.93 \\
\hline $\mathrm{CD}(\mathrm{P}=0.05)$ & 6.26 & 0.81 & 9.02 & 2.61 \\
\hline \multicolumn{5}{|c|}{ Nutrient management } \\
\hline $\mathbf{F}_{1}$ & 130.25 & 14.85 & 153.57 & 62.79 \\
\hline $\mathbf{F}_{2}$ & 117.43 & 12.09 & 122.62 & 59.64 \\
\hline $\mathbf{F}_{3}$ & 104.84 & 9.19 & 105.37 & 54.30 \\
\hline $\mathbf{F}_{4}$ & 81.28 & 6.78 & 87.34 & 49.94 \\
\hline SEm \pm & 2.00 & 0.26 & 3.22 & 0.84 \\
\hline $\mathrm{CD}(\mathrm{P}=\mathbf{0 . 0 5})$ & 5.60 & 0.72 & 9.02 & 2.34 \\
\hline
\end{tabular}

$\mathrm{C}_{1}$-Sole maize, $\mathrm{C}_{2}$-Sole soybean, $\mathrm{C}_{3}$-Maize+ soybean, 2:2, $\mathrm{C}_{4}$-Maize+ soybean, 2:4, $\mathrm{C}_{5}$ - Two rows of soybean planted in between two rows of maize, $\mathrm{C}_{6}$-One row of soybean planted in between two rows of maize, $\mathrm{F}_{1}-125 \%$ RDF, $\mathrm{F}_{2}-100 \%$ RDF, $\mathrm{F}_{3}-75 \%$ RDF, $\mathrm{F}_{4}-50 \% \mathrm{RDF}$ 


\section{Grain yield of maize $\left(q \mathrm{ha}^{-1}\right)$}

Among crop arrangements mean data of 2014 and 2015 shows that $C_{5}$ produced the highest grain yield of maize and this was comparable with $\mathrm{C}_{1}$ and $\mathrm{C}_{6}$ and they were significantly superior over rest of the treatments. While the lowest grain yield of maize was reported from 2:4 maize + soybean intercropping (40.89 q $\mathrm{ha}^{-1}$ ) system $\left(\mathrm{C}_{4}\right)$, during both the years as well as in mean data basis. Among nutrient management $125 \%$ RDF $\left(62.79 \mathrm{q}^{\mathrm{h}} \mathrm{ha}^{-1}\right)$ produced significantly higher maize grain yield over remaining treatments clearly showing the nitrogen content in leaves may have increased the cell division, elongation and dry matter of plant led to higher yield achievement. The treatment fertilized with 50\% RDF exhibited significantly lower grain yield $\left(49.94 \mathrm{q} \mathrm{ha}^{-1}\right)$. The highest maize yield depends on many factors i.e. cultivars and nitrogen fertilization (Ding et al., 2005). Panhwar et al., (2004) also concluded that fertilizer levels exhibited highly significant effect on grain yield of maize.

\section{References}

Chalka, M. K. and Nepalia, V. 2006. Nutrient uptake appraisal of maize intercropped with legumes and associated weeds under the influence of weed control. Indian Journal of Agriculture Research, 40(2): $86-91$.

Charles, M.M. 1992. The tropical Vegetable Garden: Principles for Improvement.

Ding, L., Wang, K.J., Jiang, G.M., Biswas, D.K., Xu, H., Li, L.F. and Li, H. 2005. Effects of nitrogen deficiency on photosynthetic traits of maize hybrids released in different years. Annals of Botany Doi: 10.1093/aob/mci. 244. www.aob.oupjournals.org.

Fageria, N.K. and Baligar, V.C. 2005. Enhancing nitrogen use efficiency in crop plants. Adv. Agron., 88:97-185.
Flores-Sanchez, D., Pastor, A., Janssen, B. H., Lantinga, E. A., Rossing, W. A. H., and Kropff, M. J. 2013. Exploring MaizeLegume intercropping systems in South West Mexico Agroecology and Sustainable Food Systems.

Francis, C. A. 1986. Multiple cropping systems. Macmillan, New York., p. 63.

Matusso, J.M.M., Jayne, N.M.P. and Mucheru Muna, M. 2014. Changes of soil inorganic $\mathrm{N}$, soil organic carbon and nitrogen uptake by maize and soybean under different intercropping patterns in Embu West and Tigania East Counties of Central Kenya. Academic. Research Journal of Agricultural Science and Research, 2(2):22-33.

Meena, O.P., Gaur, B.I. and Singh, P. 2006. Effect of row ratio and fertility levels on productivity, economics and nutrient uptake in maize (Zea mays) + soybean (Glycine max) intercropping system. Indian Journal of Agronomy, 51(3): 178-182.

Ning, T., Zheng, Y., Han, H., Jiang, G. and Li, Z. 2012. Nitrogen Uptake, Biomass Yield and Quality of Intercropped Spring- and Summer-Sown Maize at Different Nitrogen Levels in the North China Plain. Biomass Bioenergy, 47:9198.

Panhwar, M. A., Memon, F. H., Kalhoro, M. A. and Soomro, M. I. 2004. Performance of maize in intercropping system with soybean under different planting pattern and nitrogen levels. Journal of Applied Sciences, 4(2): 201204.

Singh, M.K., Thakur, R., Verma, U.N., Pal, S.K. and Pasupalak, S. 1998. Productivity and nutrient management of maize + blackgram intercropping as affected by fertilizer and plant density management of blackgram. Indian Journal of Agronomy, 43(3): 495-500.

Spiertz, J.H.J. and Ewert, F. 2009. Crop 
production and resource use to meet the growing demand for food, feed and fuel: opportunities and constraints. Njas-Wageningen. Journal of Life Sciences, 56:281-300.

Tandon, H. L. S. 1993. Methods of analysis of soils, plants, waters and fertilizers. Fert. Dev. Consultation org New Delhi, India, p. 138.

Thayamini, H. S. and Brintha, I. 2010.
Review on Maize based intercropping. Journal of Agronomy, 9(3): 135-145.

Undie, U.L., Uwah, D.F. and Attoe, E.E. 2012. Effect of intercropping and crop arrangement on yield and productivity of late season maize/soybean mixtures in the humid environment of South Southern Nigeria. Journal of Agricultural Science, 4(4): 37-50.

\section{How to cite this article:}

Pragya Pandey, Anshita Bajpai and Bajpai. R. K. 2020. Effect of Row Ratio and Fertility Level on Nutrient uptake by Maize in Maize-Soybean Intercropping System. Int.J.Curr.Microbiol.App.Sci. 9(06): 2204-2210. doi: https://doi.org/10.20546/ijcmas.2020.906.269 